\title{
WHERE DID WE GO WRONG?
}

\section{A critical assessment of crime prevention}

Eric Pelser and Antoinette Louw, Institute for Security Studies

eric@iss.co.za

ant@iss.co.za

The success of any policy is measured by how it is implemented and its effect. Given this, the implementation of crime prevention policy in South Africa has not had a promising start. This is hardly surprising, considering that the lead responsibility for crime prevention lies with the police, rather than with the government departments specifically focused on social issues. It is argued that the establishment of a national crime prevention centre that offers support to local communities be prioritised.

$\mathrm{S}$ outh Africa's overarching policy on crime prevention, the 1996 National Crime Prevention Strategy (NCPS), was from the outset compromised by differing political needs and competition among officials in the department of safety and security. Some years later it focuses largely on criminal justice and policing projects not, as intended, on prevention projects aimed at impacting on the supposed causes of crime. The White Paper on Safety and Security, approved by Cabinet and launched with some fanfare in 1998, has not been implemented in any systematic way in fact, many of its provisions have simply been ignored. At this stage the operational plans of the South African Police Service have a far greater impact on the development of government crime prevention programmes than either of the above.

This highlights a wide gap between policy and practice, one that can be attributed to a failure to take into account the actual requirements for policy implementation.

\section{The problem of defining crime prevention}

The first problem is one of definition - what does crime prevention mean and who is responsible for it? It has been described by criminologists as 'probably the most over-worked and least understood concept in contemporary criminology', and 'a concept of almost unending elasticity'.

Prevention is a tricky word. To prevent something means that you have the ability to predict its occurrence, and then the ability to intervene, to stop it from happening. As Paul Ekblom, a British policy analyst, puts it: crime prevention is 'action prior to the criminal event that interrupts a chain of cause and effect which would otherwise have led to the event'. ${ }^{3}$ Predicting criminal activity is complex, difficult and, ultimately, dependent on contested theories.

Also, even where a theory may to some degree make a correct prediction, there can be no guarantee that the right measures will be recommended to address the issue. Indeed, the recommended measures may not be acceptable to those expected to implement them.

The relationship between research, theory, policy and practice is seldom, if ever, straightforward. As Downes and Rock note: 
The extent to which theories are "taken up" in practice depends only in part on the energy and commitment of the theorist, the degree of empirical support for the theory, or the ease with which the theory can be translated into policy terms... [It] may have as much to do with the scope of the proposals for action, the resources required, the extent to which significant interests are engaged as parties or adversaries, and the likely ratio of costs to benefits. Even these factors are likely to be secondary to the correspondence between the theory and the policy-makers' timetables and rhetoric. ${ }^{4}$

\section{Adopting rather than adapting Western models}

In South Africa these issues are compounded by the fact that policy models have been adopted from developed countries, in particular England, Canada and the United States. These models are based on systems that are weak in South Africa, where they exist at all.

For instance, local-level crime prevention policy in these developed countries is premised on direct local accountability. It is based on the assumption that elected officials oversee government functions to ensure that these respond to and meet the needs of the electorate. Despite the political rhetoric, South Africa's proportional representation voting system, and its tiered structure of government, with its complicated and diverse spread of responsibilities, means there is little public access to decision-making and less direct accountability.

This is compounded by the fact that elected local officials have no formal oversight of the national police service. Those directly affected by crime in a particular area consequently have little influence over the way in which their local government or local police address the matter.

\section{The challenge of 'joined-up government'}

Furthermore, South Africa's National Crime Prevention Strategy and White Paper on Safety and Security provide for an integrated, multi-agency approach to crime prevention - as is practised in developed countries. But although there has been an attempt at joint prioritisation by the criminal justice cluster, budgets are still determined by individual departments and allocated to specific line functions within these departments. These line functions and their whole departments report individually on activities and expenditure. Thus, while crime prevention policy advocates an integrated approach, the way in which government operates inhibits the implementation of joint activities.

The challenge of 'joined-up government' is no doubt something that governments engaged in crime prevention strategies throughout the world must overcome. However, in South Africa the challenge is more acute: many of the departments concerned struggle to deliver on their most basic responsibilities, let alone co-ordinate priorities, budgets and activities involving other departments.

The lesson here may be that crime prevention strategies should focus initially on strengthening basic service delivery in the government departments that are central to crime prevention. These, importantly, include the departments responsible for social welfare, health and education, as well as the police, courts and prisons. Once a satisfactory level of service from these departments has been achieved, attention could shift towards the co-ordination of interdepartmental activities.

\section{The need for a national crime prevention centre} Another important difference between crime prevention practice in developed countries and in South Africa, is that in developed countries where national policy directs local crime prevention, national government has taken an active and consistent role in supporting local initiatives. This support has taken the form of policy guidance, technical assistance, and financial support.

Using a comparative study of successful community safety interventions, mostly in the developed world, the International Centre for the Prevention of Crime in Montreal recommends that achieving sustainable crime prevention requires a 'responsibility centre', to:

- provide leadership located at the highest level of government; 
- develop an implementation strategy;

- ensure that the policies of other departments contribute to the strategy; and

- stimulate partnerships (often through providing seed funding) so that key actors work together. ${ }^{5}$

In South Africa, where skills and resources are in short supply, and crime prevention is relatively new, support of this kind is vital. This is especially true when service delivery in some areas of government is weak, and special government funds aimed at developing skills for job creation among the youth, do not reach their targets.

Therefore, a national crime prevention centre in South Africa could lobby for improved delivery and provide advice on the allocation of funds to crime prevention projects. Such a centre could also encourage and support delivery on the ground by providing financial incentives in the form of seed funding, technical assistance in submitting applications for funding, as well as training, advice on what works, and research and evaluation.

It is exactly this kind of support that was advocated in the White Paper in its provisions on the establishment of a National Crime Prevention Strategy Centre. This has not been done and responsibility for crime prevention has been spread so broadly that it is difficult to pin down. Indeed, it often appears that it is the small social crime prevention unit in the police that drives most government crime prevention initiatives. This has severely limited national support for crime prevention in the country.

\section{The role of the police in crime prevention}

Given that crime prevention policy does not adequately take into account the requirements for implementation, the general lack of meaningful political support for crime prevention is not surprising. This, no doubt, is why politicians are inclined to back tough law enforcement approaches over longer-term preventive ones. $\mathrm{H}$ ard and fast policing operations are able to show quick results, while preventative initiatives can take years.

However, the role of the police in crime prevention is not clear. The move internationally from reactive policing towards more community oriented methods, like community policing and sector policing, represents attempts by the police themselves to define and engage with their role in prevention - with mixed results. Research by the Institute for Security Studies has found that in South Africa, despite policy and legislation on community policing, practical crime prevention for the police still largely amounts to setting up roadblocks, and high-density search and seizure operations. ${ }^{6}$

Moreover, the emphasis on policing has allowed other departments, such as those responsible for social welfare, education and health, to disengage from their responsibilities. It has also meant that the concept of 'safety and security', which implies an active role for players other than the police, has been downplayed.

Perhaps the core issue is that, despite the provisions of the NCPS and the White Paper on Safety and Security, public safety is still commonly viewed as a security issue to be dealt with by the criminal justice system and particularly by the police.

\section{Prevention as a social health, not a policing, issue}

The concepts of safety and crime prevention therefore need to be thought of as 'social health' issues. This would allow the crime prevention burden to be shared across a range of role players in government and civil society. It would also create political space for the longer-term interventions that, ultimately, are most important in ensuring the prevention of criminal behaviour.

This is, of course, what the NCPS set out to do in 1996. However, the responsibility for co-ordinating the NCPS was then located in the department responsible for policing. This meant that implementation of the NCPS was subject to police priorities and the short-term political prerogative to show results in the 'war against crime'. There can be little surprise, therefore, that implementation of the NCPS focused mainly on improvements to the criminal justice system, to the detriment of its other provisions.

So, to reduce the pressure for quick fixes, the lead responsibility for crime prevention should not lie 
with the police. It would be far more appropriate for this responsibility to be the core focus of the departments of the social cluster, that is, the departments of social development, health, and education. The engagement of these departments as lead agencies for crime prevention would, no doubt, assist a wider understanding of crime as a 'social health' issue rather than solely a security issue.

Most of this is already provided for in existing policy. What is needed is to refine the policy to take account of the South African context, and to breathe some life into it.

Note: This article is an extract from the recently published book Crime Prevention Partnerships: Lessons from practice, edited by Eric Pelser and published by the ISS. It is available in full text on the ISS website (www.iss.co.za) and in hard copy from the ISS in Pretoria.

\section{Endnotes}

1 P Brantingham \& F Faust, A conceptual model of crime prevention, Crime and Deliquency 22, 1976, pp 284-296.

2 A Crawford, Crime Prevention \& Community Safety: politics, policies and practice, Longman, London, 1999, p 6.

3 Quoted in A Crawford, ibid.

4 D Downes \& R Rock, Understanding Deviance: A guide to the sociology of crime and rule breaking, O xford U niversity Press, N ew York, 1998.

5 Crime Prevention Digest II: Comparative analysis of successful community safety, International Centre for the Prevention of Crime, M ontreal, 1999.

6 This observation is based on results of time-use studies carried out by the ISS in three police stations in Gauteng during 2001/02. For more on community policing in South Africa, see E Pelser, The challenges of community policing in South Africa, ISS Paper No 42, N ovember 1999, and E Pelser, J Schnetler \& A Louw, Not Everybody's Business: Community Policing in the SAPS' priority areas, ISS M onograph No 71, 2002. 